УДК $37.01 ; 614.4$

DOI: $10.24144 / 2524-0609.2021 .48 .465-468$

\author{
Shukatka Oksana \\ Doctor of Pedagogical Sciences, Associate Professor \\ Associate Professor of the Department of Physical Education and Sports \\ Lviv National University named after Ivan Franko, Lviv, Ukraine \\ shukatka1973@ukr.net \\ ORCID ID: http://orcid.org/0000-0002-2297-4709
}

\author{
Kryvoruchko Illya \\ baccaularate student \\ Lviv National University named after Ivan Franko, Lviv, Ukraine \\ kryvoruchko382@gmail.com \\ ORCID ID: http://orcid.org/0000-0003-4392-0483
}

\title{
THE HISTORICAL BACKGROUND OF LEGAL AND REGULATORY LEGISLATION ON PRESERVATION OF HEALTH IN QUARANTINE CONDITIONS
}

\begin{abstract}
The article raises an issue of preservation and strengthening health in pandemic conditions, because self-isolation and restrictions on the movement of people cause the loss of physical activity and the emergence of chronic diseases. It is known that all quarantine restrictions and rules are being created and regulated by the state at the legislative level. We appeal to the primary sources of quarantine legislation for deeper understanding of the issue. The purpose of the article is to investigate the historical background of legal and regulatory legislation on preservation of health in quarantine conditions. The following methods of analysis have been used: comparison and synthesis of theoretical data. The period of formation of quarantine legislation is divided into 3 phases: the period of the Middle Ages, the period before the First World War (the 19th century) and the postwar period. The article investigates the history of conduction of the first quarantine measures in Europe during the Middle Ages and the history of creation of the first quarantine legislation in Venice, Hetmanshchyna and the Russian Empire during the 14th - 18th centuries. It has been revealed that the rules of the fight against the spread of epidemiological diseases were established in the 19th century, the first international sanitary conventions and medical authorities in the Russian and Ottoman Empires were created to slow the spread of such dangerous diseases as cholera, plague and yellow fever, not harming the free international trade at that time. The article analyses the results of the first (1851), the fourth (1874) and the seventh (1892) International Sanitary Conferences and the positive and negative consequences of them. It also describes the creation of the first international medical organisations, such as the Office International d'Hygiène Publique (L'Office International d'Hygiene Publique), established in 1907, the Health Organization of the League of Nations, established in 1923 after the First World War, the Hygiene Committee of the League of Nations, established in 1926, and the World Health Organisation (WHO), established in April, 7, 1948 as the medical authority of the United Nations Organisation. The article generalizes the aims of the above-mentioned organisations and their contribution to the combat against the epidemiological diseases of the first half of the 20th century. It has been concluded that we should adhere to the classical principles of the preservation of health in the conditions of coronavirus pandemic to effectively withstand the spread of this virus.
\end{abstract}

Key words: pandemic; quarantine restrictions; preservation of health; sanitary and quarantine legislation; regulations.

Introduction. The background of the formation of sanitary and quarantine legislation originates in the Middle Ages, when it came to haulting the spread of terrible infectious diseases in Europe, such as cholera and plague. However, this issue was raised at the international level in 1851, when the 1 st International Sanitary Conference was held in Paris. The principles of the preservation of health in pandemic conditions, which are in force now, were fixed in the International Health Regulations in the XX century by the WHO. The issue of the preservation of health in pandemic conditions is relevant and prioritized nowadays and will remain so in the future, considering the global nature of the problem.

The formation of quarantine legislation from the Middle Ages till nowadays has contributed to the formation of the rules of behavior during quarantine: the social distance, the permanent stay at home and self-isolation in case of detecting the disease. Despite the fact that the deterrence of viruses is a priority of the state health policy system, the permanent stay at home causes the decrease of mobility, the reduction of the regular physical activity during the pandemic, resulting in well-being deterioration and the risk of exacerbation of chronic diseases.

The analysis of latest researches and publications. The scientific research of the formation of sanitary and

quarantine legislation has been outlined in research of national and foreign scientists. The group of foreign researchers [7] investigated the necessity of establishing the quarantine restrictions during the pandemic of coronavirus, particularly Peijie Chen has considered that quarantine restrictions on travelling and availability of participation in active events in nature, including the physical activity and physical exercises, will break the daily lifestyle of dozens of millions people. G.P.Nassis and P.Harmer have bewared from long-term staying home, because it causes the increase of sedentary lifestyle and therefore hypodynamy. Lijuan Mao has emphasized that the WHO didn't give sufficient guidance according to the preservation of people's health by doing daily physical exercises. B.E.Ainsworth and F.Li insist that using different safe, simple and easy-to-implement exercises at home are sufficient to escape from airborne coronavirus and maintain the optimal level of fitness [7]

N.Holybiatnikov, V.Babienko, V.Sydenko, E.Kozyshkurt have researched the history of formation of medical and sanitary legislation in Hetmanshchyna and the Russian Empire in their publications. The publications of Russian scientist Ye.Klymenko are dedicated to the history of activity of the Office International d'Hygiène Publique in 1907-1946. The Russian scientists E.Hnatyk and Yu.Dolzhenkova and the 
foreign scholars A.L. Taylor have investigated the issues, connected with the formation of the first international medical and sanitary legislation.

The purpose of the article is to study the historical background of legal and regulatory legislation on preservation and strengthening of health in quarantine conditions. The following methods of analysis have been used: comparison and synthesis of theoretical data.

The statement of basic proceeding. The first phase of the formation of sanitary and quarantine legislation covers a period of the Middle Ages: Justinian I, the emperor of the Bysantine Empire, in 532 AD commanded travelers, who arrived from epidemiologically dangerous territories, to stay in specially allotted quarantine zones for some time. This is the only one medical order that has survived to this day [3]. The national domestic rights, connected with the prevention of infected and epidemiological diseases, have been introduced for assistance of health policy for citizens in different European countries. The isolation, which wasn't the effective way of preventing diseases, was the most spread condition at that time. So, quarantine had been imposed in Venice since the mid of $14^{\text {th }}$ century, the first sanitary council was established in 1348, which was further transformed into the Sanitary Bureau in 1448, and the permanent health authority was in force in 1485 , which in 1504 was entitled the right to punish with death the citizens, who violated the quarantine restrictions of that time [1].

Analyzing such well-known legislative acts, as Charter of Liberties, considered as the first «unwritten» constitution of England, «Ruska Pravda» of the 12 th century, it's relevant to make the conclusion that the principles of preservation and strengthening health of citizens haven't been outlined in any of paragraphs.

There were certain rules of quarantine restrictions in our country, too: the hetman Samoilovych ordered to ban the merchants from Turkish city Kikizermen, where the epidemic of plague appeared, go into the cities of Hetmanshchyna. The quarantine facility in Vasylkiv was firstly established in 1740 [3].

Unfortunately, the ineffective rules of self-isolation in European countries had been acting for 6 centuries, till the mid of the 20 th century. However, the rules of combatting with the spread of epidemics, which are in force now, were imposed for the first time; the first medical authorities and international sanitary conventions were established to halt the spread of pandemics of cholera, plague and yellow fever without harming the international trade. This is the second phase of the formation of quarantine legislation.

In 1800, the Senate of the Russian Empire adopted the "Quarantine Charter», which was extended to the territory of Naddniprianska Ukraine. This document declared that violation of quarantine restrictions, forgery of quarantine documents were to be severely punished with the death penalty [3].

In 1839, the Supreme Council of Health of Constantinople was established, which consisted of delegates from the Ottoman Empire and the major maritime powers. The main tasks of this authority were: to control foreign merchant ships in Ottoman ports and to carry out anti-epidemic activities against the spread of plague and cholera [6]. Similar authorities were established in Morocco (1840) and Egypt (1846). Subsequently, in 1851 , the 1 st International Sanitary Conference in Paris was established with the participation of 12 states. As a result the International Sanitary Convention was created (on the 16th of January 1852, terminated in 1865, ratified by France, Portugal and Sardinia), which consisted of 137 articles. The document dealt with such terrible diseases as plague, cholera and yellow fever, the harmonization of maritime traffic regulations during a pandemic in the Mediterranean Sea and the control of plague and cholera, however only France and Sardinia ratified them. Subsequently, due to the ineffectiveness of the provisions in practice, those countries reversed the decision of the International Sanitary Conference $[2 ; 3]$.

Since 1857, the Hospital Regulations have been in force in the Russian Empire as one of the basic elements of preservation of health [3].

The efforts to introduce new quarantine regulations, that would satisfy states, continued: International sanitary conferences were held in Paris (1859), Constantinople (1866), Vienna (1874), Rome (1881) and other European cities until 1938 [2]. In the capital of the Austro-Hungarian Empire, the recommendations for the establishment of a Permanent International Commission on the Epidemic were adopted, which formed the basis for the constitution of the first international health organization, the International Public Health Bureau (L\&\#39;Office International d'Hygiene Publique), established in 1907 (the decision about the establishment was made in 1903) and liquidated in 1946. The aims of the organization were to collect data on the spread of epidemiological diseases and to adopt control methods, to develop international health agreements, to resolve quarantine disputes and to study national quarantine legislation. In 39 years of operation, 59 states from around the world joined the Bureau. It made an enormous contribution to the fight againse infectious diseases in the first half of the twentieth century $[2 ; 3]$.

The VII International Sanitary Conference, held in 1892, adopted and ratified the International Sanitary Convention by 14 States, which was limited in scope: the document regulated only cholera quarantine and was only used for those ships (including merchant ones) returning from East to West via the Suez Canal [2]. In 1902, the Pan American Sanitary Bureau was established, and in 1905 the Inter- American Sanitary Convention was adopted. In 1923, the first international organization was established at the League of Nations, which formed the basis of the future WHO, the Health Organization of the League of Nations. The reasons for its emergence were the consequences of the First World War, the spread of Spanish influenza in 1918, the epidemic of plague, the outbreak of chickenpox. The activities of the organization were carried out through the promotion and coordination of research on health and wellness, the establishment of international standards for medicines and the development of an international classification of diseases. The Health Organization of the League of Nations was most credited with establishing a number of committees and experts in the fields of health statistics, malaria, cancer, plague, opium and other drug control, etc., whose institutional bodies were located in Washington, Singapore, Sydney and Aleksandria [2; 5].

The third stage of the formation of quarantine regulations is the formation of medical legislation after the Second World War. This phase continues till now.

On April 7, 1948, the world-renowned organization, the World Health Organization (WHO), was established as a specialized medical agency of the United Nations, ratified by 26 member states of the United Nations. WHO, according to Article 1 of the Constitution, aims at attaining the highest possible standard of health for the peoples. This organization has many functions: cooperation with other United Nations bodies and units, research in the field of health care, improvement of the environment, nutrition and hygienic conditions for preservation and improvement of health, maternity protection, etc. One 
of the major steps taken by WHO is the adoption of the International Health Regulations in 1951 at the WHO IV Assembly. It is the first comprehensive international instrument that includes measures to prevent the spread of related infectious diseases and requirements for reporting on the occurrence and spread of viruses. They regulate measures to ensure the greatest possible protection against pandemics, without interfering with international travel and stock movement [3].

The European Social Charter was created in 1961 and signed by many European States and was signed into law in 1965. It established the obligation of state signatories to the Charter to take measures to prevent epidemiological diseases, to eliminate the causes of the deterioration of public health and to ensure the right to health care. The United Nations General Assembly adopted the International Covenant on Economic, Social and Cultural Rights in 1966, the Declaration on the Rights of Persons with Mental Disabilities was adopted in 1971 and the Declaration on the Rights of Persons with Disabilities in 1975. There are the laws and regulations that impose obligations on UN member countries: they must comply with all administrative and legislative directives regardless of their level of economic and social development [4]. In 1969, the WHO specialists adopted a new international document «International
Health Regulations» (hereinafter - IHR). These regulations extended the responsibilities of medical personnel during epidemics, proposing medical and organizational measures for the registration, containment and transmission of information on the occurrence of outbreaks of viruses. In 2005, the 50th World Assembly of WHO introduced certain amendments to IHR which came into force in May 2007. The above mentioned document indicates that the key global instrument to protect against the international spread of disease is the enactment of national quarantine legislation. It establishes rules against the containment of threats from communicable and non-communicable diseases, which spread from one country to another. The updated IHR rules were first implemented in 2006 when the influenza pandemic emerged [3].

This material leads to the conclusion that all quarantine restrictions have been implemented and proved effective under the conditions of the global coronavirus pandemic (COVID-19). It is worth mentioning that under quarantine conditions it is necessary to adhere to classical principles of health preservation and promotion: practice exercising, breathing gymnastics, outdoor walks, proper nutrition, compliance with all quarantine restrictions. It is the responsibility of each of us to respect those activities, as life and health are at stake throughout the world.

\section{Список використаної літератури}

1. Баришніков М.Р. Міжнародне медичне право та його вплив на медичне законодавство України. Концепція розвитку медичного права і законо давства України у галузі охорони здоров'я: матеріали круглого столу, м. Київ, 20 трав. 2008. Київ: Ліки України, 2008. С.188-190.

2. Гнатик Е.А., Долженкова Ю.В. Международное медицинское право: история и перспективы развития. Вестник РУДН. Серия: Юридические науки. 2014. № 2. С.281-288.

3. Голубятников Н.И., Бабиенко В.В., Сиденко В.П., Козишкурт Е.В. Санитарная охрана границ в истории формирования международного медико-санитарного законодательства (обзор). Журнал Гродненского государственного медицинского университета. 2014. № 4. С.21-26.

4. Кіндзерський B.I. Роль міжнародного та конституційного законодавства в формуванні системи охорони здоров'я в Україні. Медичне право Украӥни: правовий статус пачієнтів в Украӥні та його законодавче забезпечення (генезис, розвиток, проблеми і перспективи вдосконалення): матеріали II Всеукр. наук.-практ. конф., м.Львів, 17-18 квіт. 2008. Львів: Львівський Обласний Благодійний Фонд, 2008. С.137-143.

5. Клименко Е.П. Образование и деятельность международного бюро общественной гигиены (1907-1946 гг). Ученые записки Крымского федерального университета имени В.И.Вернадского. Юридические науки. 2015 , № 3. С.167-177.

6. Taylor A.L. Global Health Law: International Law and Public Health Policy. International Encyclopedia of Public Health. 2017. Issue 2. PP.268-281.

7. Chen P., Mao L., Nassis G.P., Harmer P., Ainsworth B.E., Li F. Coronavirus disease (COVID-19): The need to maintain regular physical activity while taking precautions. J Sport Health Sci. Volume 9, Issue 2, Mar 2020. PP.103-104.

\section{References}

1. Baryshnikov, M.R. (2008). Mizhnarodne medychne pravo ta yogo vplyv na medyche zakonodavstvo Ukrainy (The international medical law and its impact on medical legislation of Ukraine). Proceeding of the round table - Kontseptsia rozvytku medychnogo prava $i$ zakonodavstva okhorony zdorovia, materialy kryglogo stoly [The conception of the development of medical law, the Proceedings of Round-table Conference] (pp.188-190). Liky Ukrainy. [in Ukrainian].

2. Hnatyk, E.A., \& Dolzhenkova, Yu.V. (2014). Mezhdunarodnoe medytsynskoe pravo: ystoryia y perspektyvy razvytyia [The international medical law: history and perspectives of development]. Vestnyk RUDN. Seryia: Yurydycheskye nauky, 2, $281-288$. [in Russian].

3. Holybiatnikov, N.I., Babienko, V.V., Sydenko, V.P., \& Kozyshkurt, E.V. (2014). Sanytarnaya okhrana granyts v istoriy formyrovania mezhdunarodnogo medyko-sanitarnogo zakonodatel'stva (obzor). [The sanitary security of borders in the history of the formation of international medical and sanitaty legislation (a review)]. Zhynal Grodnenskogo gosydarstvennogo medytsynskogo unyversyteta, 4, 21-26. [in Russian].

4. Kindzers'kyi, V.I. (2008). Rol' mizhnarodnogo ta konstytutsiinogo zakonodavstva v formyvanni systemy okhorony zdorovia v Ukraini [The role of internatioanl and constitutional legislation in the formation of health policy system in Ukraine]. Proceeding of the 2-nd All-Ukrainian Scientific and Practical Conference - Medychne pravo Ukrainy: pravovyi statys patsientiv $v$ Ukraini ta yogo zakonodavche zabezpechennia (genezys, rozvytok, problemy i perspektuvy vdoskonalennia) [The medical law of Ukraine: the patients' legal status in Ukraine and its legal support (genesis, development and perspectives of improvement)]. L'vivs'kuy Oblastnuy Blagodiinuy Fond. [in Ukrainian].

5. Klymenko, E.P. (2015). Obrazovanie y deyatel'nost' mezhdynarodnogo biuro obshchestvennoy gygyeny (1907-1946 gg.) [The formation and activity of the Office International d'Hygiène Publique (1907-1946)]. Uchenye zapysy Krymskogo federal'nogo unyversyteta ymeny V.Y.Vernadskogo. Series: Yurydycheskye nauky, 3, 167-177.

6. Taylor, A.L. (2017). Global Health Law: International Law and Public Health Policy. International Encyclopedia of Public Health, 2, 268-281.

7. Chen, P., Mao, L., Nassis, G., Harmer, P., Ainsworth, B. \& Li, F. (2020). Coronavirus disease (COVID-19): The need to maintain regular physical activity while taking precautions. J Sport Health Sci, 9 (2), 103-104. 


\section{Шукатка Оксана Василівна}

доктор педагогічних наук, доцент доцент кафедри фізичного виховання та спорту

Львівський національний університет імені Івана Франка, м.Львів, Україна

\section{Криворучко Ілля Валерійович} студент бакалаврату

Львівський національний університет імені Івана Франка, м.Львів, Україна

\section{ІСТОРИЧНІ ВИТОКИ НОРМАТИВНО-ПРАВОВОГО ЗАКОНОДАВСТВА ЩОДО СПРИЯННЯ ЗДОРОВЯЗБЕРЕЖЕННЮ В УМОВАХ КАРАНТИНУ}

Анотація. У статті порушено питання збереження та зміцнення здоров’я в умовах пандемії, оскільки самоізоляція та обмеження пересування людей призводить до втрати фізичної активності та появи хронічних захворювань. Відомо, що усі карантинні обмеження та правила створюються та регулюються державою на законодавчому рівні. Для глибшого розуміння проблеми звертаємося до першоджерел карантинного законодавства. Метою статті є дослідження історичних витоків нормативно-правового законодавства щодо питань збереження та зміцнення здоров'я в умовах карантину. У дослідженні використовувались методи: аналізу, порівняння, узагальнення теоретичних даних. 3'ясовано, що період формування карантинного законодавства поділяється на три етапи: період Середньовіччя, період перед Першою світовою війною (19-те століття) та післявоєнний період. У статті досліджується історія проведення перших карантинних заходів у Свропі часів Середньовіччя та перших карантинних законодавств у Венеції, Гетьманщині та Російській імперії протягом 14-го-18-го століть. Виявлено, що в 19-му столітті вперше запроваджувалися правила боротьби 3 поширенням епідеміологічних захворювань, створювалися перші міжнародні санітарні конвенції та медичні органи в Російській та Османській імперіях, які мали завдання сповільнювати поширення таких небезпечних захворювань, як холера, чума та жовта лихоманка, не роблячи шкоди на той час вільній міжнародній торгівлі. Проаналізовано результати першої (1851р.), четвертої (1874р.), та сьомої (1892р.) Міжнародних санітарних конференції, позитивні та негативні наслідки їх проведення. Описано створення перших міжнародних медичних організацій, а саме: Міжнародного бюро суспільної гігієни (L'Office International d'Hygiene Publique), утвореного в 1907 році, Організації охорони здоров’я Ліги Націй, утвореної в 1923 році після Першої світової війни, Комітету гігієни Ліги Націй, утвореного в 1926 році та Всесвітньої організації охорони здоров'я (BOO3), утвореної 7 квітня 1948 року як медичний орган Організації Об'єднаних Націй. Узагальнено цілі вищенаведених організацій та їхній внесок у боротьбі з епідеміологічними захворюваннями першої половини XX століття. Підсумовано, що в умовах пандемії коронавірусу варто дотримуватися класичних засад здоров'язбереження, щоб ефективно протидіяти поширенню цього вірусу.

Ключові слова: пандемія; карантинні обмеження; здоров’язбереження; санітарно-карантинне законодавство; нормативні документи. 